\title{
Öğretmenlerin Kariyer Engelleri Ölçeğinin Geliştirilmesi
}

\section{Developing the Teachers' Career Barriers Scale}

\author{
Yusuf INANDI*, Fahrettin GILIÇ**
}

Öz: Bu araştırmanın amacı öğretmenlerin yaşadığı kariyer engellerini belirlemeye yönelik geçerli ve güvenirli bir ölçme aracı geliştirmektir. İlgili alanyazın taranarak araştırmacılar tarafından oluşturulan toplam 45 madde, hazırlanan uzman görüş formu ile 6 uzmanın görüşüne sunulmuştur. Uzmanların görüşleri doğrultusunda çıkarılan, düzeltilen ve eklenen maddelerle birlikte toplam 45 maddelik beşli likert tipi olarak derecelendirilen ölçek 315 öğretmene uygulanmıştır. Elde edilen verilerin ortaya koyduğu sonuçlar faktör analizi ile açımlanmaya çalışılmıştır. Yapılan açımlayıcı faktör analizi sonucunda ölçeğin 5 faktörden oluştuğu sonucuna ulaşılmıştır. Bu beş faktörden "yönetimden kaynaklı engeller" tek başına ortak varyansın \%37,435'ini, "siyasi/sendikal engeller" faktörü tek başına ortak varyansın \%11,298'ini, “ailevi engeller" faktörü tek başına ortak varyansın \%5,892'sini, "yükseköğrenimde bürokratik engeller" faktörü tek başına ortak varyansın \%4,680'ini ve son olarak "ekonomik engeller" faktörü tek başına ortak varyansın \%4,379'unu açıklamaktadır. 30 maddeden oluşan ölçeğin faktör yükleri .451 ile .832 arasında değişmektedir. Ölçeğin tamamı için Cronbach $\alpha$ iç tutarlık katsayısı .94, yönetimden kaynaklı engeller alt boyutu için .93, siyasi-sendikal engeller alt boyutu için .86, ailevi engeller alt boyutu için .86, yükseköğrenimde bürokratik engeller alt boyutu için .78 ve ekonomik engeller alt boyutu için .73 olarak hesaplanmıştır. Doğrulayıcı faktör analizi sonucunda elde edilen değerler, normal değer ya da kabul edilebilir değer sınırları içerisinde kalmaktadır $(\chi 2 / \mathrm{sd}=3.19)$. Bu sonuçlar öğretmenlerin Kariyer Engelleri Ölçeği'nin geçerli ve güvenilir bir ölçme aracı olduğunu ortaya koymaktadır.

Anahtar Kelimeler: Öğretmen, kariyer engelleri, geçerlik, güvenirlik

\begin{abstract}
The purpose of this study is to develop a valid and reliable measurement tool to determine the career barriers experienced by teachers. 45 items were created by the researchers through literature review and the opinion of 6 experts was taken via expert opinion form prepared by the researchers. The scale, which was graded as a five-point Likert type with 45 items that were excluded, corrected and added according to the opinions of the experts, was applied to 315 teachers. The results of the data were explained with factor analysis. As a result of exploratory factor analysis, the scale was concluded to consist of 5 factors. Of these five factors, "administrative barriers" individually accounted for $37.435 \%$ of the covariance, "political/union barriers" factor for $11.298 \%$, "family barriers" factor for 5.892\%, "bureaucratic barriers in higher education" factor for $\% 4.680$, and finally, the "economic barriers" factor for $\% 4.379$ of the covariance. The factor loadings of the 30-item scale ranged from .451 to .832 . Cronbach alpha for the internal consistency coefficient was calculated as .94 for the scale while it was found .93 for administrative barriers sub-dimension, .86 for political-union barriers sub-dimension, .86 for family barriers subdimension, .78 for sub-dimension of bureaucratic barriers in higher education, and .73 for economic barriers sub-dimension. As a result of confirmatory factor analysis, the obtained values are in between the acceptable intervals $(\chi 2 / s d=3.19)$. It can be stated according to these results that Teachers' Career Barriers Scale is a valid and reliable measurement tool.
\end{abstract}

Keywords: Teacher, career barriers, validity, reliability

\section{Giriş}

Toplumsal, ekonomik ve teknolojik gelişmelerin yansıması olarak günümüz örgütlerinin yapısal bir değişim sürecinden geçtiği görülmektedir. Buna bağlı olarak, klasik yönetim anlayışından farklı bir şekilde, çalışanların örgüt içindeki görev ve sorumlulukları kadar bireysel anlamda

\footnotetext{
*Doç. Dr., Mersin Üniversitesi, Eğitim Fakültesi, Mersin-Türkiye, ORCID:0000-0003-2760-0957, e-posta: inandiyusuf@gmail.com

** Öğretmen, Milli Eğitim Bakanlığı, Mersin-Türkiye, ORCID:0000-0003-4371-8541, e-posta:fgilic@ yahoo.com
} 
beklenti ve ihtiyaçları da farklılaşmaktadır. Bireyin çalıştığı örgütte beceri kazanma, gelişim, yükselme, saygınlık gibi ihtiyaçlarını karşılama imkânı bulabilmesi örgütün de varlığını sürdürmesi ve verimliliğini arttırması için önemlidir. $\mathrm{Bu}$ nedenle modern yönetim yaklaşımlarında insanların örgüt içi ve dışında kişisel gelişim ve yükselme ihtiyaçları da önem kazanmaya başlamıştır. Kısacası modern yönetim anlayışında çalışanlar için kariyer önemli değişkenlerden biri olarak karşımıza çıkmaktadır.

Kariyer kavramına ilişkin çeşitli tanımlar bulunmaktadır. Çalık ve Ereş (2006) genel anlamda kariyeri bireyin yaşamı boyunca sürdürdüğü işi ile ilgili pozisyonlar dizisi olarak tanımlamaktadır. Bu tanımı daha ayrıntılı bir şekilde açıklamak gerekirse, çalışanların örgütlerde kendilerine verilen iş rollerine yönelik beklentilerini, amaçlarını, duygularını ve isteklerini gerçekleştirebilmesi için eğitilmesi ve böylece sahip olduğu bilgi, beceri ve çalışma isteği ile o örgütte ilerleyerek daha fazla para kazanma arzusu olarak ifade edilebilir. Buradan anlaşılacağ 1 üzere bireysel hedefler ile örgütsel hedefler arasında bir dengenin kurulmasına işaret eden kariyer kavramı, hiyerarşik bir örgüt yapısı içinde sadece dikey anlamda yukarı doğru bir ilerleme olarak değerlendirilmektedir. Öte yandan bireyin, aynı pozisyonda veya çapraz fonksiyonlar ve yatay transferler yoluyla mevcut pozisyona eşdeğer farklı bir konumda, psikolojik olarak tatmin olacağ çalışmalar yapması, böylece bilgi kazanması ve becerilerini artırması da kariyer geliştirme olarak kabul edilmektedir (Aytaç, 2005). Kariyer ile ilgili yapılan ilk çalışmalarda kariyer kavramının bireyin örgütü ve çalışma yaşamı ile sınırlı olarak ele alındığı görülürken günümüzde kariyerin yaşam tarzından bağımsız düşünülemeyeceği bir yaklaşım benimsenmektedir (Niles ve HarrisBowlsbey, 2009). Sonuç olarak kariyer, bireyin sadece çalışma yaşamında edindiği bilgi, beceri ve deneyim değil aynı zamanda hayatın her alanında yaşadığı olaylar ve durumlar olarak görülmektedir.

Bireysel ihtiyaçların giderilmesinde önemli bir yeri olan kariyer kavramını, insanın fizyolojik, sosyolojik ve psikolojik ihtiyaçları ile birlikte değerlendirmekte yarar vardır (Çalık ve Ereş, 2006). Maslow'un ihtiyaçlar sıralamasına göre birey fizyolojik ihtiyaçlarını karşıladıktan sonra sosyolojik (sevgi, ait olma, takdir ve saygı ihtiyac1) ve nihai olarak da psikolojik (kendini gerçekleştirme) ihtiyaçlarını gidermek için çaba göstermektedir. Pines'e (1993) göre, bireyler bir işe başlarken yüksek motivasyonla başlarlar, kariyer seçimlerini yaparken kendileri için yüksek hedefler koyarlar ve bu hedeflerin gerçekleşmesi için beklentiler içerisine girerler. Bu beklentiler gerçekleşmediği zaman bireyler örgüt içinde tükenmişlik, yabancılaşma, örgütsel bağlılığın azalması, iş doyumunun düşmesi gibi çeşitli olumsuzluklar yaşayabilir. Çalışma yaşamında da birey gerek bilgi ve beceri gerekse pozisyon olarak işe başladığı noktada kalmak istemeyeceği için Maslow'un ihtiyaçlar sıralamasına benzer şekilde bir ilerleme arzusu içerisine girebilir. Bu bağlamda kariyer geliştirme bireye üst kademelere doğru yükselme firsatı verirken kişisel gelişimine de önemli bir katkı sunar (Taşlıyan, Arı ve Duzman, 2011). Ayrıca kişinin kimliğini, toplumsal durumunu ve statüsünü oluşturmasına, meslek yaşamının sürdürülebilmesi için gerekli olan maddi gücü elde etmesine, psikolojik olarak iş doyumunun sağlanmasına ve kişiliğin gelişmesine katkı sağlayabilir (Aytaç, 2005). Bununla birlikte birey mesleğinde ilerleme sürecinde iş arkadaşları, yöneticileri ve örgütün diğer paydaşları ile sürekli bir alış-veriş içerisinde olduğundan kariyer geliştirme bireyin sadece kişisel yaşamı üzerinde değil çevresi ile olan ilişkilerinde de belirleyici bir etkiye sahip olabilir (Özsoy, 2004).

Bireyin mesleki ve sosyal yaşamında ciddi bir yer tutan kariyer geliştirme sürecinin doğru planlanması ve yönetilmesi hem birey hem de örgüt açısından önemlidir. Bireysel kariyer planlama ile örgütsel kariyer yönetiminin kariyer geliştirmenin iki önemli öncülü olduğu ortaya konmuştur (Abaneh, 2013; Puah ve Anantham, 2006). Kariyer planlaması ile bireyin yaşamı boyunca yer alacağı işle ilgili görev ve pozisyonlarının, hedeflerinin ve geleceğinin planlı hale getirilmesi ifade edilmektedir (Aytaç, 2005). Bu açılamaya göre kariyer planlama, kişisel bir süreç gibi algılansa da bireyin tek başına yapabileceği şeyler veya alabileceği kararlar olarak değerlendirmemek gerekir. Kariyer geliştirmenin diğer öncülü olan kariyer yönetimi ise bireyin ilgi alanları, değerleri, güçlü ve zayıf yönleri ile kariyer amaçlarının tanımlanmasını kapsayan ve başarılabilecek kariyer hedeflerinin ulaşılabilirliğini arttıran kariyer yöntemlerini içeren bir süreçtir (Edinsel, 2018). Başarılı bir kariyer geliştirme süreci için bireysel ve örgütsel hedefler 
arasında bir uyum sağlanmasının zorunluluğu açıkça görülmektedir. Ancak bu uyumun gerçekleştirilmesi her zaman mümkün olmamakta, diğer bir ifade ile, bireysel hedefler ile örgütsel hedefler arasında bir denge oluşturulamamaktadır. Çalışanlar, kariyer hedeflerini gerçekleştirme sürecinde çeşitli engellerle karşılaşmaktadır. Bireylerin toplumda ve örgüt içinde cinsiyetten kaynaklı yaşadığı dezavantajlar vardır. Örneğin ailede her iki eşin de kariyer hedefinin olması (çift kariyerli eşler), özellikle kadınların daha fazla geri plana itilmesine neden olmaktadır. Örgütte çalışanların kendi işi dışında başka bir işte çalışması (ay ışı̆̆ı sorunu) veya bireyin sahip olduğu birden fazla uzmanlık alanı nedeniyle hangisini seçeceğine karar vermede zorlanması (çift kariyerlik) karşılaşılan sorunlardan bazılarıdır (Çalık ve Ereş, 2006). Bireyin örgüt içinde veya yaşadığ 1 çevrede etnik azınlık grup içinde yer alması da kariyer engelleri yaşamasına neden olarak gösterilebilir (Cardoso ve Marques, 2008). Cinsiyete ve etnik azınlığa bağlı olarak gelişen sorunların yaygın olarak yaşandığı söylenebilir çünkü bu sorunların ortaya çıkmasında ve gelişmesinde bireyin kontrolü yoktur.

Çalışma yaşamında kariyer engelleri ile karşılaşan bireylerin, örgüt içinde olumsuz davranışlar sergilemeleri kaçınılmaz olabilmektedir. Kariyer engelleri yaşayan çalışanların duygusal tükenme ve işine karşı duyarsızlaşma yaşadığı, kişisel başarı düzeylerinin düştüğü (İnand1, 2009), iş doyumu düzeylerinin düşük olduğu (İnand1 ve Tunç, 2012), örgütsel sessizliğe büründüğü (İnand1, Gün ve Gıllı̧, 2017), örgüte karşı yabancılaştığı (İnand1, Tunç ve Kılavuz, 2018), kararlara katılmada isteksiz davrandığı (Cenğiz, 2011), motivasyon düzeylerinin (Bilkay, 2017) ve örgütsel bağl1lıklarının azaldığ 1 (Uzkurt, 2019) ortaya konmuştur. Buna göre kariyer engellerinin çalışanın performansını ve dolayısıyla da örgütün verimliliğini olumsuz yönde etkilediği açık bir şekilde görülmektedir.

Kariyer engellerine ilişkin ulusal ve uluslar arası alanyazında birçok çalışmanın yapıldığ görülmektedir. Bu çalışmaların büyük çoğunluğu kadınların yaşadığı kariyer engellerine odaklanmıştır. Usluer (2000), hem kadınların hem de erkeklerin ve yöneticilerin toplumdaki egemen ataerkil yapıyı içselleştirdikleri için kadınların daha çok kariyer engeli yaşadıklarını belirtmektedir. Köstek (2007) ise kadınların aile, okul ve çevre, toplumsal yapı, ekonomik nedenler ve eğitim, çalışma saati, yas ve medeni durum kaynaklı kariyer engellerine maruz kaldıkları sonucuna ulaşmıştır. İnandı (2009) ve Gündüz'ün (2010) de yaptıkları araştırmada benzer sonuçları elde ettikleri görülmektedir. Bakioğlu ve Ülker'in (2018) Türk kadın akademisyenlerin yaşadığı kariyer engelleri üzerine yaptıkları araştırma bulguları, kadın akademisyenlerin kariyer rehberliği ile ilgili yeterli destek alamadıklarını, kadınların eş ve annelik rollerinin kariyerden önce geldiğini ve toplumda kadın ve erkeklere özgü mesleklere ilişkin bir önyargının var olduğunu göstermektedir. İnandı, Tunç ve Uslu (2013) da kadın akademisyenlerin yaşadıkları kariyer engelleri ile onların iş doyumu düzeyleri arasında anlamlı bir ilişkinin olduğunu ortaya koymuşlardır. Türk ve Fransız yönetici kadınlarla kariyer engellerine ilişkin karşılaştırmalı bir araştırma yapan Akpınar-Sposito (2013), coğrafi, tarihi, ekonomik ve kültürel farklılıklara rağmen kadınların kariyer geliştirme sürecinde iş-yaşam dengesi, çocuk sahibi olma, örgütün kültürü, ailenin eğitim düzeyi ve yaş durumu gibi ortak engellerle karşılaştıklarını ifade etmektedir. Henry-Brown ve Campbell-Lewis (2005), kariyer rehberliğinden yoksun olmanın ve kariyer için şehir veya ülke değiştirme gerekliliğinin kadınlar için, özellikle de siyahi kadınlar için kariyer engeli oluşturduğunu belirtmektedir. Reddy (2006) ise yaş, rrk, evlilik ve mevcut (alt kademe) yönetim pozisyonlarını kadınların önündeki kariyer engeli faktörleri olarak sıralamaktadır. Parnell, Lease ve Green'in (2012) etnik olmayan kültürel azınlık olarak kabul edilen gay, lezbiyen ve biseksüel (GLB) bireylerin yaşadığg kariyer engellerini tespit etmek amacıyla yaptıkları çalışmada GLB bireylerin cinsel yönelimleri nedeniyle örgüt içinde ayrımcılığa maruz kaldıklarını ve dolayısıyla kariyerlerini geliştiremediklerini ortaya koymuşlardır.

Kadınların ve diğer dezavantajlı azınlık grupların yaşadığı kariyer engellerine yönelik çok sayıda çalışmanın yapıldığı görülebilir. Bu durum, erkek çalışanların herhangi bir kariyer engeli yaşamadığ 1 , mesleklerinde kolay bir şekilde ilerleyip kendilerini geliştirdikleri anlamına gelmemelidir. Özellikle eğitim örgütlerinde, sadece kadınların değil aynı zamanda erkek öğretmenlerin de kariyer geliştirme sürecinde çeşitli sorunlarla baş etmek zorunda kaldıkları 
bilinmektedir. Bu sorunlar bireysel ve örgütsel faktörlerden kaynaklanabilir. Kariyer planlaması yapmak ve örgüt politikasını bilmek ve benimsemek, bireysel faktörler arasında yer alırken geri bildirim verme, ödüllendirme, örgüt içinde iyileştirme veya terfi, eğitim ve gelişim, kariyerle ilgili bilgi paylaşımı ve rehberlik desteği örgütsel faktörler olarak kabul edilmektedir (Maheswari ve Krishnan, 2004). Ayrıca öğretmenler ailevi, kişisel, bürokratik, siyasi/sendikal, yöneticilerden kaynakl1 veya yükseköğrenimde karşılaşılan çeşitli bürokratik kariyer engelleri yaşayabilmektedir. Modern toplum hayatında kadının iş yaşamında daha çok yer alması ile birlikte evle ilgili kadına atfedilen görevlerin artık erkekler tarafından da paylaşıldığ görülmektedir. Böylece erkeğin de evin içinde yemek yapma, ev temizliği, çocuğun bakımı gibi görev ve sorumlulukları benimsediği gözlenmektedir. Bundan dolayı erkek ögretmenlerin daha önce yeteri kadar var olan zamanı ve enerjisi azalmaktadır. Bunun üzerine erkek öğretmenler, kariyer geliştirme süreci için yeteri kadar zamanlarının ve güçlerinin olamayacağını düşünmeye, ailelerini ihmal etme kaygısı yaşamaya başlayabilir.

Bireyin kariyerle ilgili kişisel düşünce ve inisiyatifleri de engel olarak görülebilir. Yaşının ilerlediğini düşünen öğretmen, kariyer yapmanın anlamsız olduğunu, bunun için yeterli enerjisinin de olmadığını düşünebilir. Ayrıca kariyer geliştirme sürecinin ekonomik açıdan da bir yük getirmesi ve kariyere yapılan ekonomik yatırımın geri dönüşünün uzun vadede gerçekleşecek olması öğretmenleri kariyer geliştirmeden uzak tutan bir diğer faktör olarak değerlendirilebilir.

Bürokratik engellerin varlığ 1 da kariyer yapmanın önünde bir diğer engeldir. Öğretmenlerin özellikle lisansüstü öğrenimleri için izin konusunda ilgili mevzuatın yeterince açık olmaması ve öğrenim gördükleri şehre yer değiştirme haklarının bulunmaması, onları yüksek lisans/doktora çalışmalarına başlayamamalarına veya yarıda bırakmalarına neden olabilmektedir. Kişisel ve mesleki gelişimle ilgili kurs ve seminerlerin genellikle eğitim-öğretim dönemi içinde yapılması da öğretmenlerin katılımını güçleştirmektedir. Bunların yanı sıra daha önce bir defa yapılıp bir daha uygulanmayan uzman öğretmenlik kariyer sinavlarında görüldüğü gibi öğretmenlik mesleğinde kariyer basamaklarının belirgin olmayışı, bunu sağlayacak bir öğretmenlik meslek kanununun hala çıkarılmaması da bürokratik engeller arasında gösterilebilir.

Okul yöneticileri ve diğer üst kademe yöneticiler de öğretmenlerin kariyer geliştirme sürecinde engeller çıkarabilmektedir. Özellikle okul yöneticilerinin klasik yönetim anlayışına bağlı olarak göreve odaklandıkları ve öğretmenlerin kişisel ve mesleki ihtiyaçlarını dikkate almadıkları görülebilmektedir (İnandı, Uzun ve Yeşil, 2016). Bu nedenle öğretmenlerin kariyer geliştirmelerine yöneticilerin isteksiz olmaları, onlara yeteri kadar rehberlik etmemeleri, özverili çalışmaları ödüllendirmemeleri, kariyer geliştirme ile ilgili etkinlikler konusunda öğretmenleri bilgilendirmemeleri ve onlara kendilerini geliştirecek bir çalışma ortamı sunmamaları ögretmenler için kariyer geliştirme sürecine olumsuz yansiyabilmektedir.

Siyasal görüss ve sendikal farklılıklar da bir başka kariyer engeli olarak değerlendirilebilir. Yönetici atamalarında, bakanlığa müfettiş seçiminde, yurt dışı görev mülakatlarında veya proje okulları, bilim ve sanat merkezleri gibi kurumlara öğretmen alımında ölçme-değerlendirmeyi yapan üst düzey yöneticilerin benzer siyasi görüşteki veya belirli sendikalara üye öğretmenleri tercih edebildikleri dikkat çekmektedir. Bu durum, bir yandan bir milyonu aşan üyesiyle çok büyük ve heterojen yapıya sahip bir örgüt olan Mili Eğitim Bakanlığının homojen bir yapıya dönüşmesine yol açarken bir yandan da öğretmenlerin kendi kurumları içinde kariyer yapmasına engel oluşturabilmektedir.

Kariyer geliştirme sürecinin bir parçası olarak lisansüstü eğitim almak isteyen bir öğretmenin, yükseköğrenim ile ilgili bazı bürokratik engellerle de karşılaşması söz konusu olabilmektedir. Özellikle Bakanlık bünyesinde görev yapan öğretmenlerin lisansüstü eğitim konusunda öğrenim özrüne bağlı olarak yer değiştirme haklarının olmaması ve lisansüstü öğrenim ile öğretmenlik görevini eş zamanlı yürütmek zorunda olmaları kariyer engeli olarak değerlendirilebilir. Öte yandan, Türkiye'de yükseköğretim yönetiminin merkeziyetçi ve bürokratik bir yapı içine hapsedilmesi (Yılmaz, 2016) üniversite ve enstitü kadrolarını sinırlamakla birlikte açılan program sayısını da olumsuz etkilemektedir. Bunun sonucunda öğretmenler lisansüstü öğrenim için program çeşitliliği ve kontenjan engeline takılabilmektedir. 
Yukarıda bahsedilen engellerden hareketle, özellikle Türkçe alanyazında, hem erkek hem de kadın öğretmenlerin birlikte, kariyer geliştirme sürecinde bu sorunlardan hangileri ile karşılaştıklarını tespit etmek için bir ölçme aracının bulunmadığı görülmekte ve dolayısıyla öğretmenlerin (kadın ve erkek) yaşadığı kariyer engellerine yönelik geçerli ve güvenilir bir ölçme aracına ihtiyaç duyulmaktadır. Bu bağlamda, bu araştırmanın amacı öğretmenlerin kariyer engelleri algılarını belirlemeye yönelik geçerli ve güvenilir bir ölçme aracı geliştirmektir.

\section{Yöntem}

\section{Katılımcilar}

$\mathrm{Bu}$ araştırmanın çalışma grubu 315 öğretmenden oluşmaktadır. Açımlayıcı faktör analizinin sayıltılarını test etmek için 391 öğretmenin ölçme aracına verdiği yanıtlar "Uç değerler, tek değişkenli ve çok değişkenli normallik dağılımı, doğrusallık, R'nin faktörlenebilirliği" bakımından incelenerek ortaya konulmuştur. Bunun sonucunda 315 veri sayıltıları karşılamış, analizler bu 315 veri üzerinden yapılmıştır. Araştırmaya katılan öğretmenlere ilişkin bilgiler Tablo 1'de yer almaktadır.

Tablo 1.

Katılımcıların Demografik Değişkenlere Göre Dağılımı

\begin{tabular}{lccc}
\hline Değişkenler & & $\mathrm{n}$ & $\%$ \\
\hline \multirow{2}{*}{ Cinsiyet } & Kadın & 197 & 62,5 \\
& Erkek & 118 & 37,5 \\
\cline { 2 - 4 } Medeni durum & Evli & 250 & 79,4 \\
& Bekar & 65 & 20,6 \\
\cline { 2 - 4 } Kidem & $1-5$ & 55 & 17,5 \\
& $6-10$ & 55 & 17,5 \\
& $11-15$ & 78 & 24,8 \\
& $16-20$ & 60 & 19,0 \\
& 21 ve üzeri & 67 & 21,3 \\
\hline
\end{tabular}

Tablo 1'e göre araştırmaya 197 kadın öğretmen $(\% 62,5)$ ve 118 erkek öğretmen $(\% 37,5)$ katılmıştır. Öğretmenlerin 250'si evli $(\% 79,4)$, 65'i bekardır $(\% 20,6)$. Araştırmaya katılan öğretmenlerin kıdem açısından oranı birbirine yakın görünmektedir. Buna karşın en çok 11-15 yıl arası kıdeme sahip öğretmenler (\%24,8) araştırmaya katılım gösterirken 1-5 yıl ve 6-10 yıl kıdeme sahip öğretmenlerin oranı $(\% 17,5)$ eşit şekilde en az olarak bulunmuştur.

\section{Veri toplama aracı}

Ölçek maddelerinin yazılması ve deneme formunun hazırlanması sürecinde kariyer engellerine ilişkin alanyazın incelemesi yapılmıştır. Bunun sonucunda 45 maddeden oluşan bir madde havuzu hazırlanmıştır. Bu maddeler ile oluşturulan deneme formu, eğitim yönetimi alanında üç, ölçme değerlendirme alanında iki ve öğretim programları geliştirme alanında bir öğretim üyesi olmak üzere toplam altı uzmanın görüşüne sunulmuştur. Uzman görüşlerini almak için detaylı bir uzman görüş formu oluşturulmuştur. Uzman görüşleri doğrultusunda üç madde ölçekten çıkarılmış, beş maddede revizyon yapılmış ve üç madde eklenmiştir (DeVellis, 2016). Yapılan inceleme ve düzeltmeler sonucunda yine 45 maddelik bir deneme formu oluşturulmuştur. Ölçeğin deneme formunda yer alan her madde "5-Tamamen kat1liyorum, 4-Katıliyorum, 3-Kararsızım, 2Katılmıyorum ve 1-Hiç katılmıorum" şeklinde derecelendirilmiştir.

\section{Verilerin analizi}

Ölçeğin yapısını açıklamak amacıyla açımlayıcı faktör analizi (AFA) uygulanmıştır. Faktör analizi, birbiriyle ilişkili çok sayıda değişkeni bir araya getiren ve daha az sayıda, anlamlı yeni değişkenler sunmayı amaçlayan çok değişkenli bir istatistiktir (Büyüköztürk, 2014). Ayrıca faktör analizi ile maddelerin daha iyi çalışıp çalışmadığ 1 da test edilir (DeVellis, 2016). Ölçek geliştirme 
çalışmalarında geliştirilecek ölçeğin psikometrik özelliğinin en az hata ile belirlenebilmesi için Tabachnick ve Fidell'in (2015) faktör analizi için belirttiği minimum veri sayısı $(n=300)$ temel alınmıştır.

AFA çok değişkenli bir istatistik olduğu için eksik veri problemi, tekli ve çoklu normal dağılım, tekli ve çoklu uç değerler, çoklu bağlantı problemi, R'nin faktörlenebilirliği, hataların bağımsızlığı gibi çok değişkenli istatistiklerde yer alan temel sayıltılar incelenerek veri seti analiz için uygun hale getirilmiştir. Ölçekteki maddelerin madde toplam korelasyonları, Crobanch Alfa güvenirlik katsayısı, faktör ortak varyansları, faktör yük değerleri ve varimax döndürme sonrası faktör yük değerleri hesaplanmıştır.

Ölçme aracının yapısını belirleme sürecinde ortak varyansın 0.40 'tan ve faktör yüklerinin .45 'ten yüksek olmasına, her maddenin faktörler arası faktör yükünün .10'un altında yük vermemesine, yamaç eğim grafiğine ve açıklanan toplam varyans miktarına dikkat edilmiştir (Tabachnick ve Fidell, 2015; Tavşancıl, 2006).

Ölçeğin yapı ve kapsam geçerliğini sağlamak amacıyla, uzman görüşleri dikkate alınarak hazırlanan 45 maddelik deneme formuna toplam 391 öğretmen yanıt vermiştir. İlk olarak ölçeğin açımlayıcı faktör analizi sayıltıları incelenmiştir. Buna göre eksik veriler gözden geçirilmiş olup eksik veri probleminin olmadığı gözlenmiştir. Dolayısıyla faktör analizi için belirtilen minimum veri sayısı $(n=300)$ esas alındığında (Tabachnick ve Fidell, 2015) araştırmadaki gözlem sayısının $(n=391)$ ölçek geliştirmek için yeterli olduğuna karar verilmiştir. İkinci aşamada tek değişkenli ve çok değişkenli uç değerlerin belirlenmesi için $Z$ değerleri ve Mahalanobis uzaklıklarına bakılmıştır. $Z$ değeri +3 ile -3 aralığının dışında kalan 3 veri tek değişkenli aykırı değer olarak kabul edilirken çoklu normal dağılımı da tehdit eden $\left(\chi^{2}(30 ; 0,0001)=59,708\right)$ kritik değerinin üzerinde olan 73 gözlem çoklu aykırı değer olması gerekçesiyle analize dahil edilmemiştir. Dolayısıyla analizler 315 gözlem üzerinden yürütülmüştür. Tek değişkenli normallik, madde ortalamaları, ortancaları ve mod değerleri karşılaştırılarak incelenmiş; tüm maddelerin normal dağıldığ öngörüsüyle çok değişkenli normallik kabul edilmiştir. Çoklu bağlantı probleminin olup olmadığını incelemek için VIF ve tolerans değerleri incelenmiştir. Araştırmada yer alan üç maddenin $(39,40,41)$ VIF değerlerinin $>5$ ve tolerans değerlerinin $<.20$ olması nedeniyle çoklu bağlantı problemi olduğuna karar verilmiş ve üç madde çıkarılarak AFA 315 gözlem ve 42 madde ile yürütülmüştür. Hataların bağımsızlığını test etmek için yapılan Durbin Watson istatistiği 2,022 bulunmuştur. Hesaplanan Durbin Watson istatistiğinin, 2'ye yakın değerler alması gerekmektedir (Tabachnick ve Fidell, 2015). Bu veri setine ilişkin bulunan Durbin Watson değeri, hataların birbirinden bağımsız olduğunu göstermektedir.

Ayrıca verinin faktör analizine uygun olup olmadığının (faktörlenebilirliğinin) belirlenmesi için KMO katsayısı incelenmiştir. KMO katsayısı, 1'e yaklaştıkça verilerin analize uygun olduğu anlamına gelir (Çokluk, Şekercioğlu ve Büyüköztürk, 2018; Tabachnick ve Fidell, 2015). Örneklemin yeterliliğini değerlendirmek üzere Kaiser- Meyer-Olkin (KMO) katsayısı 0,929 olarak hesaplanmıştır. Çalışmada korelasyon matrisine ilişkin olarak Bartlett küresellik testi anlamlı bulunmuştur $\left(x_{2}=7576,980, p<.01\right)$. Belirlenen bulgular 1şı̆̆ında, elde edilen veri setinin çok değişkenli ve normal dağılım gösterdiği, dolayısıyla faktörleşmeye uygun bir yapı sergilediği şeklinde kabul edilebilir (Tabachnick ve Fidell, 2015). Döndürme tekniğini belirlemek amacıyla faktörler arasında ilişki olup olmadığı incelenmiş olup faktör puanları arasında $p<.05$ düzeyinde anlamlı bir ilişki bulunamamıştır. Bu nedenle dik döndürme tekniklerinden biri olan Varimax tekniği kullanılmıştır (Çokluk ve diğerleri, 2018; Tabachnick \& Fidell, 2015).

Ölçeğin yapı geçerliğini belirlemek ve uygulandığı grubun yapısını ortaya koyabilmek için gerekli sayıltılar sonucunda kalan 315 veriye temel bileşenler analizi uygulanmıştır. Faktör analizi aşamasında faktör yükü .32'nin altında kalan ya da iki faktördeki yük değeri farkının .10'un altında olan maddeler ölçekten atılmıştır (Çokluk ve diğerleri, 2014). Ayrıca, özdeğeri 1,00'den büyük faktörler üzerinde işlem yapılmıştır. Açımlayıcı faktör analizi sonucunda ölçeğin ve alt boyutların güvenirliği Cronbach alfa katsayısı ile belirlenmiştir (Çokluk ve diğerleri, 2018; Köklü, 2002; Tabachnick ve Fidell, 2015).

AFA ile açımlanan yapının başka bir grup üzerinde benzer yapı sergileyip sergilemediğini belirlemek için uygulanan doğrulayıcı faktör analizi (DFA) ile yapı geçerliğinin sağlanması 
amaçlanmıştır. DFA yapılması amacıyla, nihai ölçeğin yeni bir katılımcı grup üzerinde uygulaması gerçekleştirilmiş ve 290 öğretmenden veri elde edilmiştir. DFA da, AFA gibi çok değişkenli bir istatistik olduğundan, veri seti öncelikle DFA'ya hazır hale getirilmiştir. DFA'da, ölçeğin beş faktörden oluştuğu hipotezi test edilmiştir. DFA sonucunda modelin geçerliğini belirlemek amacıyla alanyazında sıklıkla kullanılan bazı uyum indisleri (ki-kare uyum testi, iyilik uyum indeksi, AGFI, CFI, RMSEA, RMR, SRMR ve NNFI) incelenmiştir (Çokluk, Şekercioğlu ve Büyüköztürk, 2014; Tabachnick ve Fidell, 2015).

\section{Bulgular}

Çalışmada öncelikli olarak, "Ağırlıklandırılmamış en küçük kareler yöntemi” kullanılmış bunun sonucunda maddelerin ortak varyansı açıklama oranları incelenerek ortak varyansı 0.40 ' 1 n altında olan madde olmadığ belirlenmiştir. Faktör yükü 0.45 'in altında olan ve birden fazla faktöre yük verip 0.10 'dan daha az fark olan maddeler sırasıyla analiz dışı tutularak faktör analizi çalışmaları tekrarlanmıştır (Çokluk ve diğerleri, 2018; Tabachnick ve Fidell, 2015). Ölçekte faktör sayısını belirlerken, yamaç eğim grafiği ve açıklanan toplam varyans miktarı ve özdeğerleri göz önünde bulundurulmuştur. Varimax analizi ile yapılan döndürme sonucunda 13 madde ölçekten atılarak özdeğeri 1,00'den büyük beş alt boyutlu 29 maddeden oluşan bir yap1 elde edilmiştir. Ölçeğe yönelik olarak ortaya konan toplam varyanslar Tablo 2 'de yer almaktadır.

Tablo 2.

Faktörlerce Açıklanan Toplam Varyans

\begin{tabular}{llcccccccc}
\hline \multirow{2}{*}{ Bileşen } & \multicolumn{3}{c}{ Başlangıç özdeğerler } & \multicolumn{2}{c}{$\begin{array}{c}\text { Karesi alınan yüklerin } \\
\text { toplam çıarımı }\end{array}$} & \multicolumn{2}{c}{$\begin{array}{c}\text { Karesi alınan yüklerin } \\
\text { döndürme toplamı }\end{array}$} \\
\cline { 2 - 9 } & Toplam & $\begin{array}{c}\text { Varyans } \\
\%\end{array}$ & $\begin{array}{c}\text { Birikimli } \\
\%\end{array}$ & Toplam & $\begin{array}{c}\text { Varyans } \\
\%\end{array}$ & $\begin{array}{c}\text { Birikimli } \\
\%\end{array}$ & Toplam & $\begin{array}{c}\text { Varyans } \\
\%\end{array}$ & $\begin{array}{c}\text { Birikimli } \\
\%\end{array}$ \\
\hline 1 & 10,812 & 37,284 & 37,284 & 10,812 & 37,284 & 37,284 & 6,440 & 22,206 & 22,206 \\
2 & 3,373 & 11,633 & 48,917 & 3,373 & 11,633 & 48,917 & 3,812 & 13,143 & 35,349 \\
3 & 1,760 & 6,069 & 54,986 & 1,760 & 6,069 & 54,986 & 3,463 & 11,941 & 47,290 \\
4 & 1,395 & 4,809 & 59,795 & 1,395 & 4,809 & 59,795 & 2,679 & 9,238 & 56,528 \\
5 & 1,310 & 4,517 & 64,312 & 1,310 & 4,517 & 64,312 & 2,257 & 7,784 & 64,312 \\
\hline
\end{tabular}

Tablo 2 incelendiğinde, ölçeğin beş faktörlü bir yapı sergilediği görülmektedir. Toplam varyanslar incelendiğinde bu beş faktörün özdeğerleri sırasıyla 1.faktör 10,812, 2.faktör 3,373, 3.faktör 1,760 , 4. faktör 1,395 ve 5 . faktör 1,310 'dur. Bu beş faktörün açıkladıkları toplam varyans ise \%63,685'tir. Sosyal bilimlerde çok faktörlü yapılar için açılanan toplam varyans için $\% 40$ ile $\% 60$ oranları yeterli kabul edildiği (Scherer, Wiebe Luther \& Adams, 1988'den akt., Tavşancıl \& Keser, 2002) dikkate alındığında beş faktörün açıkladığı varyans oranının oldukça yüksek olduğu söylenebilir. Bu faktörlere ilişkin çizilen yamaç eğim grafiği Şekil 1'deki gibidir.

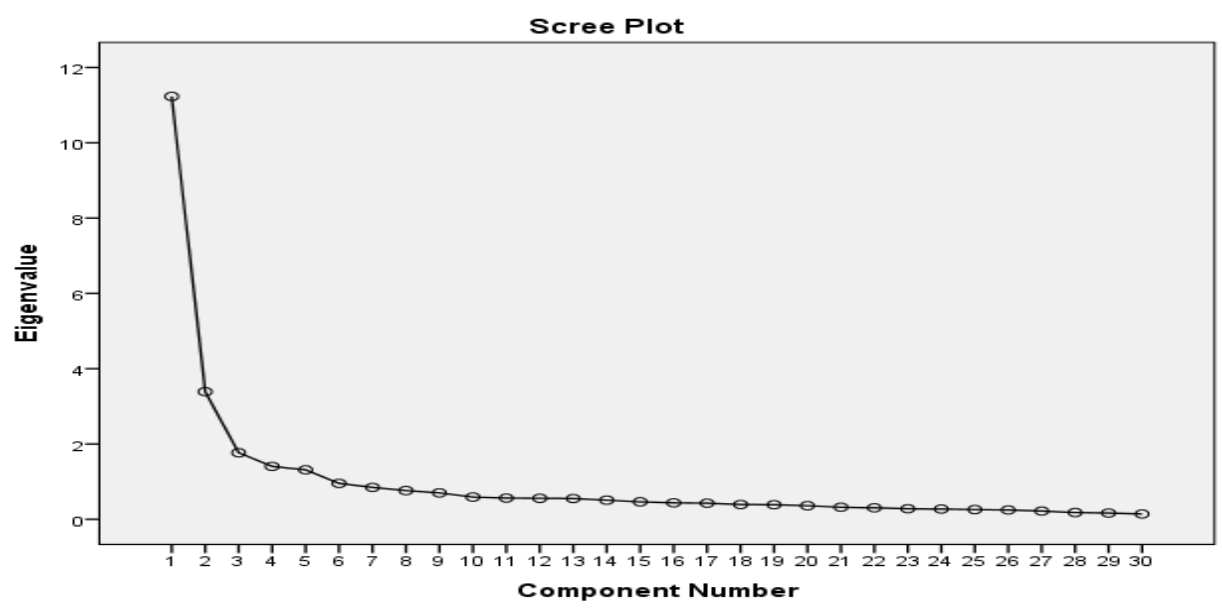

Şekil 1. Yamaç eğim grafiği. 
İnandi ve Gılıç

Şekil 1'de yer alan yamaç eğim grafiğindeki eğrinin düşüş açısı incelendiğinde de ölçeğin 5 faktörlü bir yapı sergilediği düşünülmektedir. Dolayısıyla özdeğeri açıklanan toplam varyans ve yamaç eğim grafiği sonuçları ölçeğin beş faktörlü bir yapıya sahip olduğu bulgularını desteklemektedir. Bu faktörler ve ölçekteki maddelerin bu faktörlere dağılımı, maddelerin ortak varyansı açılama oranı ve maddelere ilişkin faktör yükleri aşağıdaki Tablo 3 'te yer almaktadır.

Tablo 3.

Varimax Rotasyonuna Göre Döndürülmüş Faktör Yükleri Tablosu

\begin{tabular}{|c|c|c|c|c|c|c|}
\hline \multirow[b]{2}{*}{ Madde } & \multirow{2}{*}{$\begin{array}{l}\text { Maddelerin } \\
\text { ortak } \\
\text { varyans1 } \\
\text { açıklama } \\
\text { oranı }\end{array}$} & \multicolumn{5}{|c|}{ Faktör Yükleri } \\
\hline & & 1 & 2 & 3 & 4 & 5 \\
\hline $\mathrm{m} 30$ & ,656 & ,776 & & & & \\
\hline m33 & 670 & ,768 & & & & \\
\hline m35 & ,598 & ,756 & & & & \\
\hline m36 & ,659 & ,719 & & & & \\
\hline m37 & 634 & 718 & & & & \\
\hline $\mathrm{m} 22$ & 669 & 681 & & & & \\
\hline $\mathrm{m} 38$ & ,611 & 645 & & & & \\
\hline $\mathrm{m} 29$ & ,612 & 637 & & & & \\
\hline $\mathrm{m} 27$ & 654 & ,622 & & & & \\
\hline $\mathrm{m} 21$ & ,626 & 612 & & & & \\
\hline $\mathrm{m} 23$ & ,586 &, 583 & & & & \\
\hline $\mathrm{m} 24$ & ,604 & ,567 & & & & \\
\hline $\mathrm{m} 17$ & 645 & & ,782 & & & \\
\hline $\mathrm{m} 18$ & ,776 & &, 747 & & & \\
\hline m19 & ,741 & & ,710 & & & \\
\hline $\mathrm{m} 28$ &, 612 & &, 710 & & & \\
\hline $\mathrm{m} 26$ & 607 & & ,584 & & & \\
\hline $\mathrm{m} 6$ & ,831 & & & ,890 & & \\
\hline $\mathrm{m} 1$ & ,745 & & & ,851 & & \\
\hline $\mathrm{m} 2$ & ,691 & & & 811 & & \\
\hline $\mathrm{m} 5$ & 604 & & & ,755 & & \\
\hline $\mathrm{m} 7$ & ,535 & & & ,502 & & \\
\hline $\mathrm{m} 31$ & ,747 & & & & 817 & \\
\hline m32 & ,715 & & & & ,762 & \\
\hline $\mathrm{m} 25$ & ,446 & & & &, 522 & \\
\hline $\mathrm{m} 20$ & 495 & & & & ,508 & \\
\hline m9 & 686 & & & & & ,778 \\
\hline $\mathrm{m} 14$ & ,629 & & & & & ,701 \\
\hline $\mathrm{m} 8$ & ,565 & & & & & ,581 \\
\hline
\end{tabular}

Tablo 3'te maddelerin ortak varyanslarının 0,446 ile 0,831 arasında dağılım gösterdiği görülmektedir. Madde ortak varyanslarının .40'ın üzerinde olması ölçekte yer alan maddelerin ayırt ediciliğinin yüksek olduğu biçiminde yorumlanabilir (Büyüköztürk, 2007). 29 maddeden oluşan Öğretmenlerin Kariyer Engelleri Ölçeği, 5 faktörlü bir yapı oluşturmaktadır. Birinci faktör olan "Yönetimden Kaynaklı Engeller" alt faktörü 12 madde, ikinci faktör "Siyasi-Sendikal Engeller" alt faktörü 5 madde, üçüncü faktör "Ailevi Engeller" alt faktörü 5 madde, dördüncü faktör "Yükseköğrenimde Bürokratik Engeller" alt faktörü 4 madde ve beşinci faktör "Ekonomik Engeller" alt faktörü ise 3 maddeden oluşmaktadır. Yönetimden kaynaklı engeller alt faktöründeki maddelerin faktör yükleri ,567 ile ,776 arasında, siyasi-sendikal engeller alt faktöründeki maddelerin faktör yükleri ,782 ile ,584 arasında, ailevi engeller alt faktöründeki maddelerin faktör yükleri ,890 ile ,502 arasında, yükseköğrenimde bürokratik engeller alt faktöründeki maddelerin faktör yükleri ,817 ile ,508 arasında ve ekonomik engeller alt 
faktöründeki maddelerin faktör yükleri ,778 ile ,581 arasında değişmektedir. Ölçekte yer alan maddeler ve faktör isimleri Tablo 4'te verilmiştir.

Tablo 4.

Ölçekte Yer Alan İfadeler ve Faktör İsimleri

\begin{tabular}{|c|c|c|}
\hline Faktör Ad1 & Madde $\mathrm{No}$ & İfadeler \\
\hline \multirow{12}{*}{$\begin{array}{l}\text { Yönetimden } \\
\text { Kaynaklı } \\
\text { Engeller }\end{array}$} & $\mathrm{m} 30$ & Yöneticilerin öğretmenleri kariyer geliştirme konusunda teşvik etmemesi \\
\hline & m33 & $\begin{array}{l}\text { Yöneticilerin seminer, kurs vb konularda öğretmenleri yeterince } \\
\text { bilgilendirmemeleri }\end{array}$ \\
\hline & $\mathrm{m} 35$ & $\begin{array}{l}\text { Okuluma eğitimle ilgili konularda seminer vermek üzere uzmanların davet } \\
\text { edilmemesi }\end{array}$ \\
\hline & $\mathrm{m} 36$ & $\begin{array}{l}\text { Bakanlığın, öğretmenlerin kariyer geliştirme sürecinde yeterince teşvik edici } \\
\text { olmaması }\end{array}$ \\
\hline & m37 & $\begin{array}{l}\text { Genel kültür ve alanımla ilgili bilimsel süreli yayınların okula ulaşması } \\
\text { konusunda yeterince caba gösterilmemesi }\end{array}$ \\
\hline & $\mathrm{m} 22$ & $\begin{array}{l}\text { Yöneticilerin, mesleki ve kişisel gelişim seminerlerine katılmamda engel } \\
\text { çıarması }\end{array}$ \\
\hline & $\mathrm{m} 38$ & $\begin{array}{l}\text { Kariyer sınavları (yöneticilik, müfettişlik, yurt dışı görev sınavları gibi) ile ilgili } \\
\text { konularda tesvik edici bir uygulamanın olmaması }\end{array}$ \\
\hline & $\mathrm{m} 29$ & Öğretmen olarak fazladan çabalarımın göz ardı edilmesi \\
\hline & $\mathrm{m} 27$ & Yöneticilerin, öğretmenlerin kariyer gelişim sürecine olumsuz bakmaları \\
\hline & $\mathrm{m} 21$ & Yöneticilerin kişisel kapris ve düşünceleri \\
\hline & $\mathrm{m} 23$ & $\begin{array}{l}\text { Bakanlığın, öğretmenlerin gelişimine yönelik düzenlediği etkinliklerin } \\
\text { (seminer, kurs vb. ) yetersiz olması }\end{array}$ \\
\hline & $\mathrm{m} 24$ & $\begin{array}{l}\text { Öğretmenlerin gelişimi için açılan kurslara katılmada objektif kriterlerin } \\
\text { kullanılmaması }\end{array}$ \\
\hline \multirow{5}{*}{$\begin{array}{l}\text { Siyasi- } \\
\text { Sendikal } \\
\text { Engeller }\end{array}$} & $\mathrm{m} 17$ & Sendikal tercihlerin kariyer geliştirme sürecinde etkili olması \\
\hline & $\mathrm{m} 18$ & Kariyer ilerlemesinde değerlendirmenin tarafsız yapılmaması \\
\hline & $\mathrm{m} 28$ & Sivil toplum örgütlerinin (vakıf, dernek, siyasal, sendika, vb) müdahaleleri \\
\hline & $\mathrm{m} 19$ & Öğretmenlerin kariyer basamakları kriterlerinin objektif olmamas1 \\
\hline & $\mathrm{m} 26$ & Üst kademe yöneticiler ile farklı dünya görüșünde olunması \\
\hline \multirow{5}{*}{$\begin{array}{l}\text { Ailevi } \\
\text { Engeller }\end{array}$} & m6 & Kariyer sürecinde eşimi ve çocuğumu ihmal edebilirim kaygısı \\
\hline & $\mathrm{m} 1$ & elişim süresince ailemi ihmal \\
\hline & $\mathrm{m} 2$ & Ailevi sorumlulukların çok olması \\
\hline & m5 & Bence evli olmak kariyer yapmanın önünde önemli bir engel \\
\hline & $\mathrm{m} 7$ & Ailevi desteğimin bulunmaması \\
\hline \multirow{4}{*}{$\begin{array}{c}\text { Yüksek } \\
\text { öğrenimde } \\
\text { Bürokratik } \\
\text { Engeller }\end{array}$} & $\mathrm{m} 31$ & Yükseköğretim kurumlarındaki alana ilişkin lisansüstü kontenjan sınırlılıkları \\
\hline & $\mathrm{m} 32$ & eköğretim kurumlarındaki alana ilişkin lisansüstü program çeşitliliğindeki \\
\hline & $\mathrm{m} 25$ & Lisansüstü öğrenim ile öğretmenlik görevinin es zamanlı vürütülmesi \\
\hline & $\mathrm{m} 20$ & Lisansüstü eğitim için yer değiştirme imkânının olmaması \\
\hline \multirow{3}{*}{$\begin{array}{l}\text { Ekonomik } \\
\text { Engeller }\end{array}$} & $\mathrm{m} 9$ & ecek olm \\
\hline & $\mathrm{m} 14$ & \\
\hline & $\mathrm{m} 8$ & Kariyer sürecinin zaman zaman farklı șehirlerde bulunmayı gerektirmesi \\
\hline
\end{tabular}

Öğretmenlerin Kariyer Engelleri Ölçeği'nin güvenirliğine ilişkin iç tutarlılık katsayıları hesaplanmıştır. Ölçeğin iç tutarlılığını gösteren Cronbach Alfa katsayısı, ölçeğin tamamı için .93, yönetimden kaynaklı engeller alt faktörü için .93, siyasi-sendikal engeller alt faktörü için .86 , ailevi engeller alt faktörü için .86 , yüksekögrenimde bürokratik engeller alt faktörü için .78 ve ekonomik engeller alt faktörü için .73 olarak hesaplanmıştır.

Ölçeğin AFA sonucu ortaya çıkarılan yapısının geçerliğini test etmek için (DeVellis, 2016) 290 yeni veri üzerinden gerçekleştirilen doğrulayıcı faktör analizi (DFA) sonucunda elde edilen model, Şekil 2'de görülmektedir. Yapılan t-testleri sonucunda, Şekil 2'de verilen DFA modelindeki tüm faktör yüklerinin istatistiksel olarak anlamlı olduğu belirlenmiştir $(p<0,05)$. 
İnandi ve Gılıç

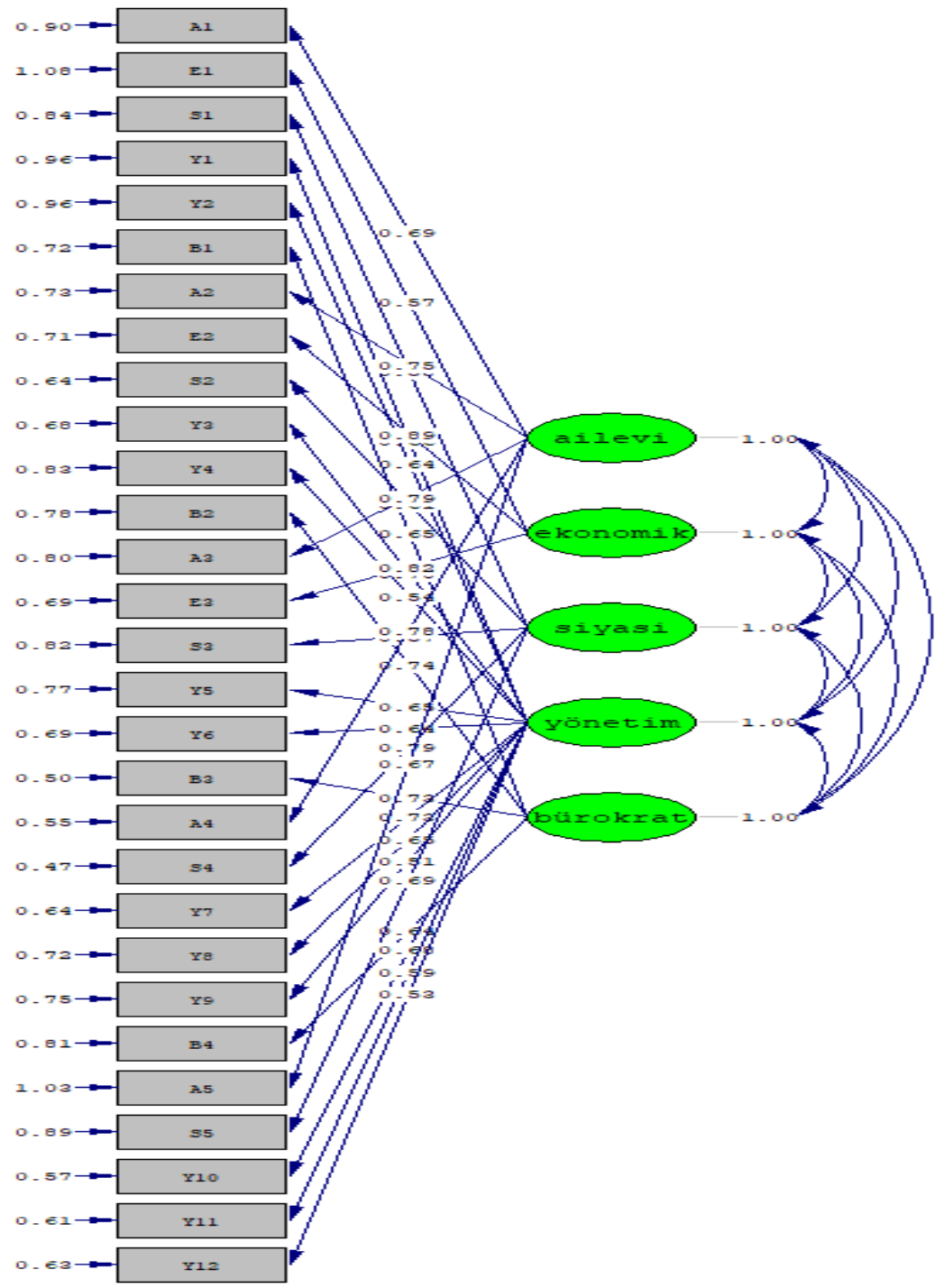

Şekil 2. DFA Sonucunda Elde Edilen Ölçme Modeli Ve Kestirilen Değerler

Test edilen ölçme modeline ilişkin uyum indeksleri ve bu indeksler için kabul edilen değerlendirme ölçütleri (Çokluk, Şekercioğlu ve Büyüköztürk, 2014; Tabachnick ve Fidell, 2015; Yılmaz ve Çelik, 2009) Tablo 5'te yer almaktadır.

Tablo 5.

Uyum İndeksleri ve Kabul Edilen Değerler

\begin{tabular}{cccc}
\hline İndeks & Normal değer & $\begin{array}{c}\text { Kabul edilebilir } \\
\text { değer }\end{array}$ & Hesaplanan değer \\
\hline$\chi^{2} \mathrm{p}$ değeri & $\mathrm{p}>0,05$ & - & - \\
$\chi^{2} / \mathrm{sd}$ & $<2$ & $<5$ & $1172,07 / 367=3,19$ \\
GFI & $>0,95$ & $>0,90$ & 0,78 \\
AGFI & $>0,95$ & $>0,90$ & 0,74 \\
CFI & $>0,95$ & $>0,90$ & 0,92 \\
RMSEA & $<0,05$ & $<0,10$ & 0,087 \\
RMR & $<0,05$ & $<0,10$ & 0,098 \\
SRMR & $<0,05$ & $<0,08$ & 0,079 \\
NNFI & $0,00-1,00$ arasi & - & 0,91 \\
\hline
\end{tabular}


Tablo 5 incelendiğinde hesaplanan değerler, normal değer ya da kabul edilebilir değer sinırları içerisinde kalmaktadır (Kline, 2005; Tabachnick ve Fidell, 2015). Bu bulgu model uyumunun sağlandığını ortaya koymaktadır. $\chi 2=1172,07(\mathrm{sd}=367)$ istatistiğinin anlamlı olduğu $(\mathrm{p}<0,05)$ gözlenmiştir ve $\chi 2 / \mathrm{sd}=3.19$ olarak hesaplanmıştır. Elde edilen bu değer, modelin kabul edilebilir bir uyum iyiliğine sahip olduğunu göstermektedir.

\section{Tartışma, Sonuç ve Öneriler}

$\mathrm{Bu}$ bölümde, geliştirilen ölçme aracının yapısı elde edilen boyutlara göre alanyazındaki çalışmalarla desteklenerek açıklanmış ve bu doğrultuda öneriler getirilmiştir. Öğretmenlerin yaşadığ Ölçeği, beş alt boyutlu olup her biri "1 (hiç katılmıyorum) ile 5 (tamamen katılıyorum" arasında derecelendirilen 30 maddeden oluştuğu görülmektedir. Yapılan AFA sonucunda yamaç eğim grafiği ve madde yük değerleri incelenerek ortaya çıkarılan birinci alt boyut (ailevi engeller) 5 madde, ikinci alt boyut (ekonomik engeller) 3 madde, üçüncü alt boyut (siyasi/sendikal engeller) 5 madde, dördüncü alt boyut (yönetimden kaynaklı engeller) 13 madde ve son olarak beşinci alt boyut (yüksekögrrenimde bürokratik engeller) 4 maddeden oluşmaktadır. Ölçekten alınacak en düşük puan 30 , en yüksek puan 150 'dir. Buna göre ölçekten elde edilen puan yükseldikçe öğretmenlerin yaşadığı kariyer engellerinin arttığı ifade edilebilir.

AFA sonucunda ortaya çıkan beş alt boyut, kariyer engellerine ilişkin geliştirilen çeşitli ölçme araçları ile kısmen benzerlik gösterirken farklılıkların daha fazla olduğu görülmektedir. Bu çalışmanın sonuçlarına benzer şekilde, Köstek (2007) ve İnandı'nın (2009) kadın öğretmenlerin kariyer engellerine ilişkin geliştirdikleri ölçekte de ailevi ve ekonomik engeller alt boyutlarının bulunduğu görülmektedir. Ancak söz konusu ölçeklerde, farklı olarak " "toplumsal yapı”, "okul ortamı ve çevre" ile "eğitim, cinsiyet, çalışma saati, yaş ve medeni durum" gibi alt boyutlar da yer almaktadır. Bu çalışmalarda sadece kadın öğretmenlerin kariyer engellerine odaklanılması, bu farkın kaynağı olarak gösterilebilir. İnandı ve diğerlerinin (2013), eğitim fakültesi öğretim elemanlarının kariyer engellerini belirlemeye yönelik geliştirdikleri ölçme aracında ise "demografik değişkenler", "görüş farklılıkları", "kaynak yetersizliği", "kurumsal ilişkiler" ve "meslektaş tutumları" olmak üzere beş alt boyut mevcuttur. Bunlardan görüş ayrılıkları, bu çalışmada geliştirilen ölçme aracının siyasi/sendikal engeller alt boyutu ile benzerlik gösterdiği söylenebilir. Buna karşın, diğer boyutların farklılık göstermesi, kariyer engellerinin farklı örgütsel yapıya ve kültüre sahip örgütlerde (üniversite ve okul) yaşanmasına bağlanabilir. Son olarak, Swanson, Daniels ve Tokar (1996) tarafından geliştirilen kariyer engelleri ölçeği 13 alt boyuttan oluşmaktadır: Cinsiyet ayrımcılığı, güven eksikliği, çoklu rol çatışması, çocuk-kariyer çatışması, 1rk ayrımcıllı̆ı, öz-yeterlik eksikliği, onaylanmama, karar verme güçlükleri, kariyer memnuniyetsizliği, geleneksel olmayan meslekleri seçememe, sağlıkla ilgili engeller, iş piyasası kısıtlamaları ve kariyer haritası belirsizliği. Çoklu rol çatışması ve çocuk-kariyer çatışması, bu çalışmada ortaya çıkarılan ailevi engeller ile benzerlik gösterirken kariyer haritası belirsizliği de "Öğretmenlerin kariyer basamakları kriterlerinin objektif olmaması" ifadesi ile örtüştügünden siyasi/sendikal engeller ile paralellik gösterdiği görülmektedir. Çalışma yaşamında yer alan her evli insanın ailevi sorumlulukları da olduğu dünya genelinde geçerli bir durum iken kariyer basamaklarının net olmaması, örgütsel bir sorun olarak değerlendirilebilir. Öte yandan bu çalışmada geliştirilen ölçme arac1, Türkiye'de görev yapan öğretmenlerin kariyer engelleri ile sınırlandırıldığı için Swanson ve diğerleri (1996) tarafından geliştirilen ölçme aracındaki diğer alt boyutlar ile sosyal, kültürel ve örgütsel açıdan farklılıklar bulunmaktadır.

Alanyazın incelendiğinde öğretmenlerin kariyer geliştirme sürecinde ailevi ve ekonomik engellerle karşılaştığı görülmektedir. Günümüzde kadınların iş yaşamında daha çok yer almasıyla birlikte erkeğin eş ve baba olarak geleneksel rolleri değişime uğramış ve gerek ev işlerinde gerekse çocuk bakımında daha fazla sorumluluk alan, eşiyle işbirliği yapan "yeni baba ve eş" imaj1 doğmuştur (Avşar, 2017; Zeybekoğlu, 2013). Bu yeni imajı ile erkekler kariyer geliştirme sürecinde "ailesini ihmal etme kaygısını" daha çok hissettikleri görülmektedir. Ayrıca kariyer sürecinde yapılan masrafın ve çekilen zahmetin geri dönüşü kısa vadede mümkün olmayabilir. 
Öğretmenin bireysel ve mesleki gelişimi için yaptığı harcama onun beşeri sermayesine yaptığ yatırım olarak değerlendirildiğinde bu yatırım ile elde edeceği bilgi ve beceriler onun verimliliğini arttırdığı (Tilak, 2002) oranda ve hızda kazancını yükseltmeyebilir. "Kariyer sürecinde yaptığ 1 masrafın kısa vadede geri dönmeyecek olması" öğretmenlerin kariyer geliştirme sürecinde isteksiz olmalarına veya tereddüt yaşamalarına neden olabilmektedir.

Öğretmenlerin siyasi/sendikal engellerle de karşılaştıkları görülmektedir. Gelişmiş ülkelerdeki kamu kurumlarının örgütsel yapılarının değişen siyasi iktidarlardan bağımsız olarak düzenli, istikrarlı bir sistem içinde çalışanlarına ne zaman ve hangi yeterlikler ile hangi pozisyonlara erişebileceklerini öngören bir kariyer haritası sunması (Edinsel, 2018), bu doğrultuda bireysel ve örgütsel açıdan bir kariyer planlamasına imkan vermesi (Aytaç, 2005) ile çalışanlar, karar verici konumundaki "üst kademe yöneticiler ile farklılaşan dünya görüşüne" sahip olsalar dahi kariyer hedefleri doğrultusunda ilerleyebilmektedir. Ancak az gelişmiş veya gelişmekte olan ülkelerde kamu kurumlarının amaç ve hedefleri siyasi iktidar ile birlikte değişebildiği için farklı görüşteki öğretmenler ile bu hedeflere ulaşmak mümkün olamayacağından aynı dünya görüşünü paylaşmak kariyer geliştirme sürecinde geçerli bir ölçüt olarak değerlendirilebilir. Kariyer yönetimi, örgütsel kariyer geliştirmenin önemli bir öncülü olarak tanımlanırken kariyer geliştirme sürecinde farklı politika ve uygulamalara ilişkin örgütsel etkinlikleri içerir (Ndegwa, Gachunga, Ngugi ve Kihoro, 2016). Bunun başarılı bir şekilde gerçekleştirilmesi ancak üst yönetim ile aynı siyasi görüşleri paylaşarak uyum içinde görev yapabilecek öğretmenlerle mümkündür.

Yöneticilerin olumsuz yaklaşım ve davranışları da öğretmenler için kariyer engeli oluşturmaktadır. Klasik yönetim anlayışına sahip yöneticiler, otokratik liderlik davranışları sergileyerek (İnand1, Uzun ve Yeşil, 2016) öğretmenleri "kariyer geliştirme sürecinde rehberlik etmediği", "teşvik edici olmadı̆̆ı" ve "kişisel kaprislerle" olumsuz bir yaklaşım içine girdiği görülmektedir. Bundan dolayı öğretmenler, okul içinde veya dışında, kariyer geliştirmeye ilişkin etkinliklere katılmakta sorun yaşayabilmektedir.

Bunların yanında, akademik kariyer yapmak isteyen öğretmenler yükseköğrenimle ilgili çeşitli engellerle karşılaşmaktadır. Bu engeller bünyesinde görev yaptığı Milli Eğitim Bakanlığına ilişkin mevzuattan kaynaklandığ 1 gibi yükseköğretim kurumlarının bürokratik yapısından da kaynaklanabilir. Öğretmenlerin "lisansüstü öğrenim için farklı şehirlere yer değiştirme hakkının olmaması" ve "öğretmenlikle lisansüstü eğitimi eş zamanlı yürütmek zorunda olması" Bakanlık kaynaklı engeller olarak görülürken "yüksek lisans/doktora programlarına ilişkin sınırlı kontenjan olması" veya istenilen "programın açılmaması" yükseköğretim kurumlarından kaynaklanan engeller olarak değerlendirilebilir.

Ulusal ve uluslar arası alanyazında, genel olarak cinsiyet ve azınlık grupları dikkate alınarak çok sayıda kariyer engelleri ölçeği geliştirildiği dikkate alındığında öğretmenlerin (kadın ve erkek) yaşadığı kariyer engellerini tespit etmeyi amaçlayan bu ölçeğin alanyazındaki söz konusu boşluğu doldurarak gelecekteki araştırmalar için katkı sağlayacağı düşünülmektedir. Yapılan AFA sonuçları ölçeğin geçerliğine kanıt sunarken iç tutarlılığını gösteren Cronbach Alfa katsayısı (.93) ise ölçeğin güvenirliğini göstermektedir. Dolayısıyla gerek akademik araştırmalar gerekse Bakanlık tarafindan öğretmenlerin kariyer engellerine ilişkin yapılacak değerlendirme için bu ölçekten yararlanılması öngörülmektedir.

Farklı değişkenler (cinsiyet, kıdem, yaş vb.) açısından ölçme değişmezliğinin incelenmesi ve ölçme aracının farklı örneklemler ile tekrar test edilmesi, ölçeğin geçerlik ve güvenirliğine ek kanıt oluşturabilir. Bunun yanında kariyer engelleri ile iş doyumu, örgütsel bağl1lık, örgütsel sinizm, tükenmişlik, yabancılaşma, stress, örgütsel özdeşleşme ve işten ayrılma niyeti gibi farklı örgütsel davranışlar arasındaki ilişkinin incelenmesi de kariyer engelleri ölçeğinin geçerlik ve güvenirliğinin yeniden elde edilmesini sağlayabilir.

\section{Kaynaklar}

Abaneh, R. (2013). Antecedents and outcomes of career development in Jordanian public sector. Journal of Emerging Trends in Economic and Management Sciences, 4(4), 417-426. 
Akpınar-Sposito, C. (2013). The glass ceiling: Structural, cultural and organizational career barriers for French and Turkish women executives. Procedia - Social and Behavioral Sciences, 75, 488-497.

Avşar, S. (2017). Toplumsal cinsiyet rolleri bağlamında tarihsel rollerini yitiren erkekliğin çöküşü: Küllerinde “yeni erkek”liğin doğuşu. KADEM Kadın Araştırmaları Dergisi, 3(2), 224-241.

Aytaç, S. (2005). Çalı̧̧ma yaşamında kariyer: yönetimi, planlaması, gelişimi ve sorunları. (2. Bask1). Bursa: Ezgi Kitabevi.

Bakioğlu, A. ve Ülker, N. (2018). Career barriers faced by Turkish women academics: Support for what? Journal of Higher Education, 8(3), 313-321.

Bilkay, T.A. (2017). Çalışan kadınların kariyer engelleri ve cam tavan sendromu algılamalarının iş motivasyonlarını etkilerini belirlemeye yönelik bir araştırma: Sağlık Bakanlığı merkez teşkilat örneği (Yayımlanmamış yüksek lisans tezi). Gazi Üniversitesi Sosyal Bilimler Enstitüsü, Ankara.

Büyüköztürk, Ş. (2014). Sosyal Bilimler İçin Veri Analizi El Kitabı. Ankara: Pegem Akademi.

Cardoso, P. ve Marques, J.F. (2008). Perception of career barriers: The importance of gender and ethnic variables. International Journal of Educational \& Vocational Guidance, 8, 49-61.

Cenğiz, G. (2011). Kadın öğretmenlerin kariyer engellerini algllamalarına göre kararlara katılım düzeyleri (Yayımlanmamış yüksek lisans tezi). Çanakkale Onsekiz Mart Üniversitesi Sosyal Bilimler Enstitüsü, Çanakkale.

Çalık, T. ve Ereş, F. (2006). Kariyer yönetimi: Tanımlar, kavramlar, ilkeler. Ankara: Gazi Kitabevi.

Çokluk, Ö., Şekercioğlu, G. ve Büyüköztürk, Ş. (2018). Çok Değişkenli İstatistik SPSS ve LISREL Uygulamaları. (5. Bask1). Ankara: Pegem Akademi Yayınları.

DeVellis, R. F. (2016). Ölçek geliştirme kuram ve uygulamalar. (T. Totan, Çev. Edt.). Ankara: Nobel Yayın Dağıtım.

Edinsel, S. (2018). Kişiliğin ve örgütsel kariyer planlamanın bireysel kariyer planlama ile kariyer memnuniyeti üzerine etkisi: Bankacıllk sektöründe $Y$ kuşă̆ (Yayımlanmamış doktora tezi). Süleyman Demirel Üniversitesi Sosyal Bilimler Enstitüsü, Isparta.

Gündüz, Y. (2010). Öğretmen algılarına göre kadın öğretmenlerin kariyerlerinin incelenmesi. Abant İzzet Baysal Üniversitesi Dergisi, 10(1), 133-149.

Henry-Brown, R. ve Campbell, L. (2005). Examining barriers to career advancement among females of color in the federal career service. Race, Gender \& Class, 12(3/4), 31-46.

Inand1, Y. (2009). The barriers to career advancement of female teachers in Turkey and their levels of burnout. Social Behaviour and Personality, 37(8), 1143-1152.

İnand1, Y. ve Tunç, B. (2012). Kadın öğretmenlerin kariyer engelleri ile iş doyum düzeyleri arasındaki ilişki. Ĕgitim Bilimleri Araştırmaları Dergisi, 2(2), 203-222.

İnand1, Y., Tunç, B. ve Uslu, F. (2013). Eğitim fakültesi öğretim elemanlarının kariyer engelleri ile iş doyumları arasındaki iliş̧i. Eğitim Bilimleri Araştırmaları Dergisi, 3(1), 219-238.

İnand, Y., Uzun, A. ve Yeşil, H. (2016). The relationship between principals' leadership styles and their efficacy in change management. Journal of Educational Sciences Research, 6(1), 191-209.

İnand1, Y., Gün, M. E. ve Gılıç, F. (2017). The study of relationship between women teachers' career barriers and organizational silence: Viewpoint of women and men teachers. European Journal of Contemporary Education, 6(3), 542-556.

İnand1, Y., Tunç, B. ve Kılavuz, T. (2018). Women's career barriers and Professional alienation: The teachers' case in Turkey. International Online Journal of Educational Sciences, 10(3), 133-146.

Kline, R. B. (2005). Principles and Practice of Structural Equation Modeling. (2nd edition). New York: Guilford Publications, Inc.

Köklü, N. (2002). Açıklamalı İstatistik Terimleri Sözlüğü. Ankara: Nobel Yayın Dağıtım. 
Köstek, H. (2007). Resmi ilköğretim okullarında çalışan yönetici ve öğretmen görüşlerine göre, kadın öğretmenlerin kariyer engelleri (Yayımlanmamış yüksek lisans tezi). Yıldız Teknik Üniversitesi Sosyal Bilimler Enstitüsü, İstanbul.

Maheshwari, S. K. ve Krishnan, T. N. (2004). Career effectiveness and its determinants. IIMA Working Papers. Indian Institute of Management, Ahmedabad, Research and Publication Department. Erişim adresi: https://web.iima.ac.in/assets/snippets /workingpaperpdf/200405-06sunilm.pdf

Ndegwa, R. M., Gachunga, H., Ngugi, K. ve Kihoro, J. (2016). Career Management an Antecedent of Career Development and it's Effect on Employees' Commitment in Public Universities in Kenya. The Strategic Journal of Business and Change Management, 3, 2(8), 168-182.

Niles, S. G. ve Harris-Bowlsbey, J. (2009). Career development interventions in the 21st century. (Third edition). New Jersey: PearsonEducationMerrill.

Özsoy, O. (2004). Değişen dünyada meslek seçimi: geleceğin meslekleri. (4. Bask1). İstanbul: Hayat Yayıncilik.

Parnell, M. K., Lease, S. H. ve Green, M. L. (2012). Perceived career barriers for gay, lesbian and bisexual individuals. Journal of Career Development, 39(3), 248-268.

Pines, A.M. (1993). Burnout: An existential perspective. W. B. Schaufeli, C. Maslach ve T. Marek (Yay. haz.). Professional Burnout: Recent Developments in Theory and Research. Philadelphia, PA: Taylor \& Francis.

Puah, P. ve Anantham, S. (2006). Exploring the antecedents and outcomes of career development initiatives: Empirical evidence from Singaporean employees. Research and Practice in Human Resource Management, 14(1), 112-142.

Reddy, P. (2006). An investigation of the barriers that impede the career advancement of women in management (Yüksek lisans tezi, Western Cape Üniversitesi, Cape Town). Erişim adresi: http://citeseerx.ist.psu.edu/viewdoc/download?doi=10.1.1.833.951\&rep=rep1\&type=pdf

Swanson, J. L., Daniels, K. K. ve Tokar, D. M. (1996). Assessing perceptions of career-related barriers: The career barriers inventory. Journal of Career Assessment March, 4, 219-244.

Tabachnick, B. G. ve Fidell, L. S. (2015). Using multivariate analysis. California State University Northridge: Harper Collins College Publishers.

Taşlıyan, M., Arı, N. Ü. ve Duzman, B. (2011). İnsan kaynakları yönetiminde kariyer planlama ve kariyer yönetimi: İ̈BF öğrencileri üzerinde bir alan araştırması. Organizasyon ve Yönetim Bilimleri Dergisi, 3(2), 231-241.

Tavşancıl, E. (2006). Tutumların ölçülmesi ve SPSS ile veri analizi. Ankara: Nobel Yayın Dağıtım Tavşancıl, E. ve Keser, H. (2002). İnternet kullanımına yönelik Likert tipi bir tutum ölçeğinin geliştirilmesi. Eğitim Bilimleri ve Uygulama, 1(1), 79-100.

Tilak, J. B. G. (2002). Education and poverty. Journal of Human Development, 3(2), 191-207.

Usluer, L. (2000). Kadın ögretmenlerin yönetici konumlara yükseltilmeme nedenleri konusundaki ögretmen ve yönetici görüşlerinin değerlendirilmesi (Yayımlanmamış yüksek lisans tezi). Ankara Üniversitesi Sosyal Bilimler Enstitüsü, Ankara.

Uzkurt, B. K. (2019). Kadınların kariyer engelleri ile örgütsel bağlllıkları arasındaki ilişkiyi ölçmeye yönelik Ankara'daki OSB'lerde bir araştırma (Yayımlanmamış yüksek lisans tezi). Ankara Yıldırım Beyazıt Üniversitesi Sosyal Bilimler Enstitüsü, Ankara.

Yılmaz, D. V. (2016). Türk yükseköğretiminde uluslararasılaşma: Tarihsel perspektiften bir analiz. Sosyal Bilimler Dergisi, 3(9), 154-172.

Zeybekoğlu, Ö. (2013). Günümüzde erkeklerin gözünden babalık ve aile. Akdeniz Üniversitesi Sosyal Bilimler Dergisi, 3(1), 297-328.

\section{Extended Abstract}

\section{Introduction}

As a reflection of social, economic and technological developments, it is seen that today's organizations are going through a structural change process. Accordingly, in a way different from 
the classical management approach, the expectations and needs of the employees differ as well as the duties and responsibilities of the employees within the organization. The capacity of the individual to meet the needs of the organization in which he works, such as gaining skills, development, promotion and respectability, is important for the organization to maintain its existence and increase its productivity. Therefore, personal development and promotion needs of people inside and outside the organization have gained importance in modern management approaches. In short, career is one of the important variables for employees in modern management approach.

Career is defined in general as a series of positions related to the individual's job throughout his life. To explain this definition in more detail, it is to train the individual to realize his/her expectations, aims, feelings and desires related to his/her job role in the workplace, and thus to make more money with his knowledge, skill and work desire, to assume more responsibility and more status, power and dignity. Today, career is seen not only as the knowledge, skills and experience acquired by the individual in working life, but also as events and situations in every area of life.

Individuals start a job with high motivation, set high goals for themselves when making career choices and expect to achieve these goals. When these expectations are not realized, individuals may experience various negative effects such as burnout, alienation, lower organizational commitment, and lower job satisfaction. It can be seen that there are many studies on career barriers experienced by women and other disadvantaged minority groups. This should not mean that male employees do not experience any career barriers and that they can easily progress and develop in their professions. Especially in educational organizations, it is known that not only women but also male teachers have to deal with various problems in the career development process. Therefore, it was aimed in this study to develop a valid and reliable measurement tool to determine the career barriers of teachers in general.

\section{Method \\ Study group}

The study group of this research consists of 315 teachers working in the central districts of Mersin in the fall semester of 2019-2020 academic year. The study group was determined by simple random sampling method.

\section{Data collection tool}

As a result of literature review on career barriers, a pool of 45 items was prepared. The pre-scale form created with these items was submitted to the opinion of a total of six experts. A detailed expert opinion form was created to obtain expert opinions. As a result of the revision and corrections, a 45-item form was created for application. Each item in the scale was graded as "5Completely agree, 4-Agree, 3-Neutral, 2-Disagree and 1-Never disagree".

\section{Analysis of the data}

As a result of the analyzes, item-total correlations of items in the scale, Crobanch Alfa reliability coefficient for internal consistency, factor covariances, factor load values and post-rotation factor load values were calculated. It was taken into consideration when deciding the structure of the scale that the common variance was higher than 0.40 , factor loadings were greater than .45 , interfactor load of each item did not load below .10 as well as regarding slope graph and total variance explained. Confirmatory factor analysis showed that the scale gives a good fit index.

\section{Results and Discussion}

The Teachers' Career Barriers Scale, which was developed in order to determine the career barriers experienced by teachers, is composed of five sub-dimensions and consists of 30 items, each graded between 1 (disagree) and 5 (totally agree). As a result of the EFA, the first subdimension (family barriers) consists of 5 items, the second sub-dimension (economic barriers) of 3 items, the third sub-dimension (political/union barriers) of 5 items, the fourth sub-dimension 
(administrative barriers) of 13 items and the fifth sub-dimension (bureaucratic barriers in higher education) of 4 items. The lowest score to be taken from the scale is 30 and the highest score is 150. Accordingly, it can be stated that as the score obtained from the scale increases, so do the career barriers experienced by teachers.

Considering that a number of career barriers scales, taking into account gender and minority groups in general, have been developed in the national and international literature, this scale, which aims to identify career barriers experienced by teachers (male and female), is thought to fill the gap in the literature and contribute to future researches. While the results of the EFA provide evidence for the validity of the scale, the Cronbach's alpha coefficient (.94), which shows its internal consistency, presents the reliability of the scale. Therefore, it is foreseen that this scale will be used for both academic research and evaluation of teachers' career barriers by the Ministry of National Education.

\section{EK-1. Örnek Ölçek Formu}

\section{KARIYYER ENGELLERİ ÖLÇEĞİ}

AÇIKLAMA: Değerli ögrretmenim, bu araştırma ile ögrretmenlerin kariyer engellerine yönelik alguları incelenmektedir. Ölçekte kariyer engellerine yönelik 45 madde bulunmaktadır. Vereceğiniz bilgiler yalnızca bilimsel amaçlı kullanılacak olup herhangi bir kişi ya da kurumla paylaşılmayacaktır. Soruları içtenlikle yanıtlamanız araştırmanın sonuçlarının geçerli ve güvenilir olması açısından önemlidir. Değerli katkılarınız için şimdiden teşekkürler.

\section{KISSiSEL BILLGILER}

Doç. Dr. Yusuf INANDI

Mersin Üniversitesi Eğitim Fakültesi

Fahrettin GILIÇ

Eğitim Yönetimi Doktora Öğrenci

1. Cinsiyet: ( ) Kadın ( ) Erkek

2. Yaş: ...........

3. Mesleki Kıdem: ( ) 1-5 yıl

yıl üstü

4. Medeni Durum: ( ) Evli ( ) Bekâr

5. Çocuk Sayısı: ( ) Yok $\begin{array}{llll}\text { () } 1 & \text { ( ) } 2 & \text { ( ) } 3 \text { ve daha fazla }\end{array}$

6. Haftalık Çalışma Saati:

7. Yönetici Olmak İstiyor Musunuz? ( ) Evet ～( ) Hayır

\begin{tabular}{|c|c|c|c|c|c|c|}
\hline & & 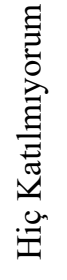 & 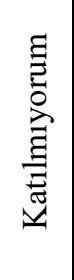 & 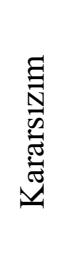 & 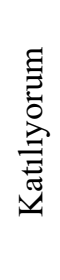 & 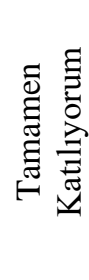 \\
\hline \multicolumn{7}{|c|}{ AILEVVI ENGELLELER } \\
\hline 1 & Kariyer gelişim süresince ailemi ihmal ederim kaygısı & 1 & 2 & 3 & 4 & 5 \\
\hline 2 & Ailevi sorumlulukların çok olması & 1 & 2 & 3 & 4 & 5 \\
\hline 3 & Bence evli olmak kariyer yapmanın önünde önemli bir engel & 1 & 2 & 3 & 4 & 5 \\
\hline 4 & Kariyer sürecinde eşimi ve çocuğumu ihmal edebilirim kaygısı & 1 & 2 & 3 & 4 & 5 \\
\hline 5 & Ailevi desteğimin bulunmaması & 1 & 2 & 3 & 4 & 5 \\
\hline
\end{tabular}




\begin{tabular}{|c|c|c|c|c|c|c|}
\hline \multicolumn{7}{|c|}{ KISSISEL/EKONOMIK ENGELLER } \\
\hline 6 & $\begin{array}{l}\text { Kariyer sürecinin zaman zaman farklı şehirlerde bulunmayı } \\
\text { gerektirmesi }\end{array}$ & 1 & 2 & 3 & 4 & 5 \\
\hline 7 & $\begin{array}{l}\text { Kariyer sürecinde yaptığım masrafın kısa vadede geri dönmeyecek } \\
\text { olması }\end{array}$ & 1 & 2 & 3 & 4 & 5 \\
\hline 8 & Lisansüstü öğrenimin ekonomik açıdan bana bir yük getirmesi & 1 & 2 & 3 & 4 & 5 \\
\hline \multicolumn{7}{|c|}{ SIYASI/SENDIKAL ENGELLER } \\
\hline 9 & Sendikal tercihlerin kariyer geliştirme sürecinde etkili olması & 1 & 2 & 3 & 4 & 5 \\
\hline 10 & Kariyer ilerlemesinde değerlendirmenin tarafsız yapılmaması & 1 & 2 & 3 & 4 & 5 \\
\hline 11 & Öğretmenlerin kariyer basamakları kriterlerinin objektif olmaması & 1 & 2 & 3 & 4 & 5 \\
\hline 12 & Üst kademe yöneticiler ile farklı dünya görüşünde olunması & 1 & 2 & 3 & 4 & 5 \\
\hline 13 & $\begin{array}{l}\text { Sivil toplum örgütlerinin (vakıf, dernek, siyasal, sendika, vb) } \\
\text { müdahaleleri }\end{array}$ & 1 & 2 & 3 & 4 & 5 \\
\hline \multicolumn{7}{|c|}{ YÖNETIMDEN KAYNAKLI ENGELLER } \\
\hline 14 & Yöneticilerin kişisel kapris ve düşünceleri & 1 & 2 & 3 & 4 & 5 \\
\hline 15 & $\begin{array}{l}\text { Yöneticilerin, mesleki ve kişisel gelişim seminerlerine katılmamda } \\
\text { engel çıkarması }\end{array}$ & 1 & 2 & 3 & 4 & 5 \\
\hline 16 & $\begin{array}{l}\text { Bakanlığın, öğretmenlerin gelişimine yönelik düzenlediği } \\
\text { etkinliklerin (seminer, kurs vb. ) yetersiz olması }\end{array}$ & 1 & 2 & 3 & 4 & 5 \\
\hline 17 & $\begin{array}{l}\text { Ögretmenlerin gelişimi için açılan kurslara katılmada objektif } \\
\text { kriterlerin kullanılmaması }\end{array}$ & 1 & 2 & 3 & 4 & 5 \\
\hline 18 & $\begin{array}{l}\text { Yöneticilerin, öğretmenlerin kariyer geliş̧im sürecine olumsuz } \\
\text { bakmaları }\end{array}$ & 1 & 2 & 3 & 4 & 5 \\
\hline 19 & Öğretmen olarak fazladan çabalarımın göz ardı edilmesi & 1 & 2 & 3 & 4 & 5 \\
\hline 20 & $\begin{array}{l}\text { Yöneticilerin öğretmenleri kariyer geliştirme konusunda teşvik } \\
\text { etmemesi }\end{array}$ & 1 & 2 & 3 & 4 & 5 \\
\hline 21 & $\begin{array}{l}\text { Yöneticilerin seminer, kurs vb konularda öğretmenleri yeterince } \\
\text { bilgilendirmemeleri }\end{array}$ & 1 & 2 & 3 & 4 & 5 \\
\hline 22 & $\begin{array}{l}\text { Okuluma eğitimle ilgili konularda seminer vermek üzere uzmanların } \\
\text { davet edilmemesi }\end{array}$ & 1 & 2 & 3 & 4 & 5 \\
\hline 23 & $\begin{array}{l}\text { Bakanlığın, öğretmenlerin kariyer geliştirme sürecinde yeterince } \\
\text { teşvik edici olmaması }\end{array}$ & 1 & 2 & 3 & 4 & 5 \\
\hline 24 & $\begin{array}{l}\text { Genel kültür ve alanımla ilgili bilimsel süreli yayınların okula } \\
\text { ulaşması konusunda yeterince çaba gösterilmemesi }\end{array}$ & 1 & 2 & 3 & 4 & 5 \\
\hline 25 & $\begin{array}{l}\text { Kariyer sınavları (yöneticilik, müfettişlik, yurt dışı görev sınavları } \\
\text { gibi) ile ilgili konularda teşvik edici bir uygulamanın olmaması }\end{array}$ & 1 & 2 & 3 & 4 & 5 \\
\hline 26 & $\begin{array}{l}\text { Üniversite yönetiminin öğretmenlerin kariyer geliştirme konusunda } \\
\text { istekli olmaması }\end{array}$ & 1 & 2 & 3 & 4 & 5 \\
\hline \multicolumn{7}{|c|}{ YÜKSEKÖĞRETIM ENGELLERİ } \\
\hline 27 & Lisansüstü eğitim için yer değiştirme imkanının olmaması & 1 & 2 & 3 & 4 & 5 \\
\hline 28 & Lisansüstü öğrenim ile öğretmenlik görevinin eş zamanlı yürütülmesi & 1 & 2 & 3 & 4 & 5 \\
\hline 29 & $\begin{array}{l}\text { Yükseköğretim kurumlarındaki alana ilişkin lisansüstü kontenjan } \\
\text { sınırlılıkları }\end{array}$ & 1 & 2 & 3 & 4 & 5 \\
\hline 30 & $\begin{array}{l}\text { Yükseköğretim kurumlarındaki alana ilişkin lisansüstü program } \\
\text { çeşitliliğindeki sınırlılıklar }\end{array}$ & 1 & 2 & 3 & 4 & 5 \\
\hline
\end{tabular}

